\title{
Proses Nominalisasi Deverbal dalam Bahasa Madura
}

\author{
Alfin Fuji Hidayati ${ }^{1}$, Ika Nurhayani' ${ }^{2}$, Nurul Choyimah ${ }^{3}$
}

1,2,3 Universitas Brawijaya, Indonesia

\begin{abstract}
Keywords:

Deverbal

Nominalization;

Madura

Language

\section{Kata kunci:}

Deverbal

Nominalization;

Bahasa

Madura

Abstract: Maintaining the local language has been one of the interests of many researchers. This is because Indonesia has a diversity of local languages. in order to preserve the local language. This study aims to analyze the verbalization nominalization process in the Madurese language. This type of research is qualitative descriptive research. The source of the data was taken from vocabulary in the short story book Tora (satengkes carpan Madura) by Jamal D. Rahman. The technique used in data collection was reading technique, recording words containing deverbal nouns and then classifying them based on the affixes attached to the word. The results showed that the prefixes -ka, - pa, -ta, -be, -sa and the suffixes -en and -an could be used in producing new lexemes in Madura. Conficts that contribute more to the formation of new words.

Abstrak: Mempertahankan bahasa lokal telah menjadi salah satu ketertarikan di antara banyak peneliti. Hal ini di karekanakan Indonesia memiliki keragaman bahasa lokal. dalam rangka melestarikan bahasa lokal. Penelitian ini bertujuan untuk menganalisis proses nominalisasi deverbal dalam Bahasa Madura. Jenis penelitian ini merupakan penelitian deskriptif kualitatif. Sumber data diambil dari kosakata dalam buku cerpen Tora (satengkes carpan Madura) karya Jamal D. Rahman.Teknik yang digunakan dalam pengumpulan data adalah teknik membaca, mencatat kata-kata yang mengandung nomina deverbal kemudian mengklasifikasikannya berdasarkan imbuhan yang melekat pada kata tersebut. Hasil penelitian menunjukkan bahwa prefiks - ka ,-pa, -ta, -be, - sa dan sufiks -en dan -an dapat digunakan dalam memproduksi leksem baru di Madura. Konfik yang lebih banyak berkontribusi dalam pembentukan kata baru.
\end{abstract}

\section{Alamat Korespondensi: \\ E-mail: Alfinfuji633@gmail.com (Hidayati)}

\section{Pendahuluan}

Banyak ahli bahasa telah tertarik melakukan penelitian tentang bahasa lokal. Salah satu bahasa lokal yang menarik perhatian penulis adalah bahasa Madura karena penelitian tentang bahasa Madura yang menyangkut proses nominalisasi masih sangat sedikit yang meneliti. Nominalisasi adalah kata kerja dan kata sifat yang direalisasikan secara linguistik sebagai kata benda (Dzarna, 2016; Laily et al., 2021). Dalam hal ini, kata kerja atau kata sifat dapat berubah menjadi kata benda ketika afiks melekat pada kata tersebut. Salah satu kelas kata utama adalah nominalisasi yang digunakan untuk mengatur klausa dan kalimat. Oleh karena itu, nominalisasi deverbal merupakan salah satu cara untuk menciptakan kata baru yang juga mengalami perubahan makna. Dalam hal ini nominalisasi deverbal adalah salah satu cara untuk mengubah makna baru yang komplek dikarenakan akan memiliki berbagai makna (Fabregas \& Marin, 2011). Kata benda yang berasal dari kata kerja dianggap memiliki berbagai makna dan ditandai dengan objek yang kongkrit tindakan, peristiwa, sopan santun, proses dll.

Nominalisasi adalah jenis metafora gramatikal yang prosesnya diwujudkan oleh kata kerja metaforis, yang juga diwujudkan oleh kata benda yang mengekspresikan proses yang sama dengan kata kerja. Dengan cara ini, fungsi kata akan berubah secara otomatis setelah melalui proses nominalisasi (Effendy, 2017). Nominalisasi adalah salah satu cara alternatif untuk merestrukturisasi atau menyusun ulang item linguistik seperti kata kerja dan mengubahnya menjadi kata benda dengan menambahkan imbuhan. Demikian pula dengan bahasa Madura yang juga memiliki imbuhan

$\begin{array}{ll}\text { History: } & \\ \text { Received } & \text { : O4 Mei } 2021 \\ \text { Revised } & \text { : O7 Mei } 2021 \\ \text { Accepted } & \text { : 30 Juni } 2021 \\ \text { Published } & \text { : 25 Juli } 2021\end{array}$

Publisher: Undiksha Press

Licensed: This work is licensed under a Creative Commons Attribution 3.0 License

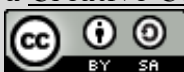


tersendiri untuk membentuk kata benda dari kata kerja (Astuti et al., 2021). Sebagian besar bahasa Madura menggunakan awalan dan akhiran untuk mengubah kata kerja menjadi kata benda, baik lisan maupun tulisan. Dalam bahasa Madura, untuk membuat kata benda dari kata kerja, banyak dilakukan dengan menambahkan awalan dan akhiran (Humaidi, 2019; Laily et al., 2021; Mardatillah et al., 2020). Kata benda yang merupakan turunan dari kata kerja yang disebut deverbal kata benda (nominalization). Kata benda deverbal memiliki jangkauan makna yang bervariasi ketika awalan ditambahkan sebelum akar kata dan akhiran setelah akar kata.

Semua bahasa memiliki proses afiksasi, termasuk bahasa Madura. Para ahli bahasa mengatakan bahwa afiksasi muncul dalam semua bahasa, seperti Prancis, Spanyol, Jerman, Latin, Rusia, Arab, dan Indo-Eropa lainnya (Kharisma \& Arvianto, 2019; We \& Fauziah, 2020). Oleh karena itu, dengan adanya imbuhan sebelum dan sesudah akar kata dapat membuat kata menjadi lebih kompleks, namun tetap memiliki makna dan dapat dipahami dengan baik. Morfem terikat adalah afik yang biasanya selalu bergabung dengan akar kata atau batang sebelum dan sesudahnya. Berkaitan dengan ini, mempertahankan bahasa lokal adalah hal yang sangat penting agar tidak terjadi kepunahan bahasa local (Aditya Dharma, 2019; We \& Fauziah, 2020). Bahasa Madura merupakan bahasa daerah yang kaya akan keunikan dan ciri khas yang tidak dimiliki bahasa lain (Humaidi, 2019; Muslimah et al., 2019). Selanjutnya, beberapa aspek keunikan yang dimiliki orang Madura adalah dalam aspek fonologi, morfologi, dan sintaksis. Jadi, inilah salah satu alasan Madura harus dipertahankan.

Berkaitan dengan proses morfologi yang menghasilkan kata-kata baru melalui proses afiksasi, seperti prefiks, sufiks, infiks, dan konfiks, secara jelas dinyatakan bahwa proses morfologis dikategorikan menjadi infleksi, derivasi, dan pemajemukan. Dalam penelitian ini, kata benda dan kata kerja akan menjadi topik pembahasan karena keduanya memiliki pola yang berbeda tergantung pada afik yang menempel pada kata tersebut. Kata benda dapat diturunkan dari kata kerja atau kata sifat, kata kerja juga dapa diperoleh dari kata benda atau kata sifat, kata sifat juga bisa diperoleh dari kata benda atau kata kerja; dan hal ini juga berlaku untuk kata keterangan yang dapat diperoleh dari kata sifat atau kata benda. Namun yang akan menjadi fokus pembahasan adalah kata benda yang berasal dari kata kerja dalam cerpen Tora (satengkes carpan Madura). Tujuan penelitian ini yaitu menganalisis proses nominalisasi deverbal dalam bahasa madura.

\section{Metode}

Metode penelitian ini adalah metode deskriptif kualitatif. Penelitian ini diambil dari kata-kata dan bukan angka, maka penelitian ini dianggap sebagai penelitian kualitatif. Penelitian kualitatif digunakan untuk mengkaji sesuatu yang berhubungan dengan fenomena sosial. Dalam penelitian ini, peneliti merupakan instrumen kunci (Sugiono, 2018). Penelitian kualitatif adalah penelitian yang membahas fenomena sosial dengan cara membandingkan, membedakan, menganalisis, mengklasifikasikan, mendeskripsikan dan juga membandingkan satu objek dengan objek lainnya (Sugiono, 2014). Sumber data diambil dari kosakata dalam buku cerpen Tora (satengkes carpan Madura) karya Jamal D. Rahman tahun (2017). Teknik yang digunakan dalam pengumpulan data adalah teknik membaca, mencatat kata-kata yang mengandung nomina deverbal kemudian mengklasifikasikannya berdasarkan imbuhan yang melekat pada kata tersebut. Untuk mengetahui proses terjadinya kaidah morfologi dari setiap afiks pembentuk deverbal noun dalam cerpen Tora (satengkes carpan Madura), diperlukan pohon morfologi untuk memecah afiks yang melekat pada akar kata.

\section{Hasil dan Pembahasan}

\section{Hasil Penelitian}

Jenis nominalisasi rendah, nominalizer menggabungkan langsung dengan akar sebelum akar itu digabungkan dengan argumen apa pun, dan untuk jenis nominalisasi tinggi, di mana nominalizer menggabungkan dengan frasa yang lebih besar(Baker \& Gondo, 2020). Nominalisasi deverbal adalah proses pembentukan kata kerja menjadi kata benda. Ada berbagai afiks dalam bahasa Madura untuk 
membentuk kata kerja menjadi kata benda, yaitu prefiks, sufiks, infiks dan konfiks. Hanya ditemukan satu prefiks yang melekat pada morfem dalam cerpen ini. Kemudian, ditemukan sembilan sufiks, satu konfiks dan satu infiks. Prefiks yang membentuk kata benda adalah awalan $p a-$ yang disebut sebagai nominal prefix. Meskipun terdapat banyak prefiks dalam bahasa Madura, peneliti hanya menemukan prefik $p a-$ dalam cerpen Tora. Berikut adalah data yang ditemukan dalam kumpulan cerita pendek Tora:

\section{Awalan pang-}

pangaterro andhi manto sogi.... (hal.333). Kata yang dicetak tebal, leksem pangaterro adalah contoh kata yang mendapat pelekatan awalan panga-. Kemudian diilutrasikan dalam diagram pohon morfologi sebagai berikut:

a. Pangaterro

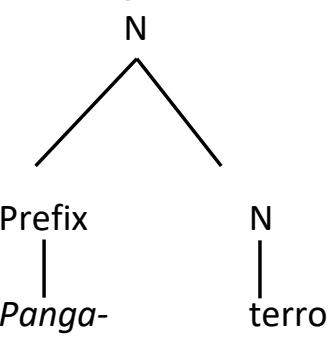

Data nomor satu menunjukkan bahwa salah satu kata dasar yang mendapat awalan pangaberfungsi untuk mengubah kata kerja menjadi kata benda. Kata terro (ingin) menjadi pangaterro (keinginan, mimpi) setelah mendapat awalan panga-. Selanjutnya kata kerja terro telah berubah kelas kata dan fungsinya dalam kalimat setelah mendapat prefiks panga-. Kata benda yang terbentuk dari proses morfologi tersebut adalah kata benda abstrak karena kategori kata berubah sehingga disebut perubahan kelas (class changing).

\section{Akhira (-an)}

pekkeran se terros agumantong (p.326). Kata yang diketik dalam huruf tebal adalah kata benda deverbal, berikut adalah proses morfologis dari kata Pekker $(v)+$ suffik $/$-an $/=$ pekkeran (n).

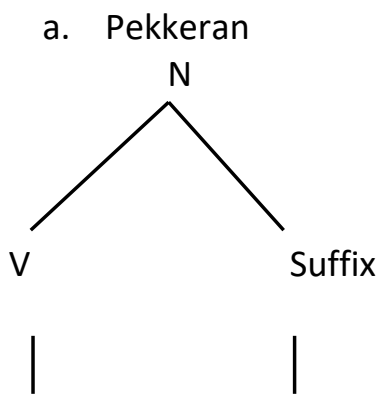

Mekker (v) -an

Dari diagram tersebut menunjukkan bahwa penempelan akhiran -an setelah kata dasar, menciptakan leksem baru yang termasuk dalam kelas kata dasar yang berbeda. Kata dasarnya berasal dari kata kerja mekker. Akibatnya, akar kata pekkeran adalah mekker. Fonem $m$ dalam kata mekker akan berubah menjadi bilabial " $p$ " jika dilampirkan pada akar yang dimulai dengan fonem $/ m$ dan b/. Akar kata adalah kata kerja, yang berarti "berpikir". Kemudian, kata tersebut berubah makna menjadi "ide" setelah mendapat akhiran -an. Sebagai sufiks yang juga dapat mengubah kategori kata, 
setelah mendapat sufiks -an, kelas kata dari akar kata pekker yang merupakan kata kerja berubah menjadi kata benda abstrak. Menurut Davies, (2010), sufiks - an adalah "suatu kegiatan atau hasil dari X. proses ini dikategorikan sebagai perubahan kelas karena sufiksnya dapat mengubah kategori kelas kata.

\section{Konfix (ka-an)}

...ngagunge bennya' kadhatengan (p. 331). Kata yang diketik dengan huruf tebal adalah kata benda deverbal. Proses morfologinya dapat diilustrasikan sebagai berikut Kadhatengan (Ka-dhateng an), kata di atas merupakan salah satu deverbal noun yang mendapat konfiks $k a-$-an.

a. Kadhatengan

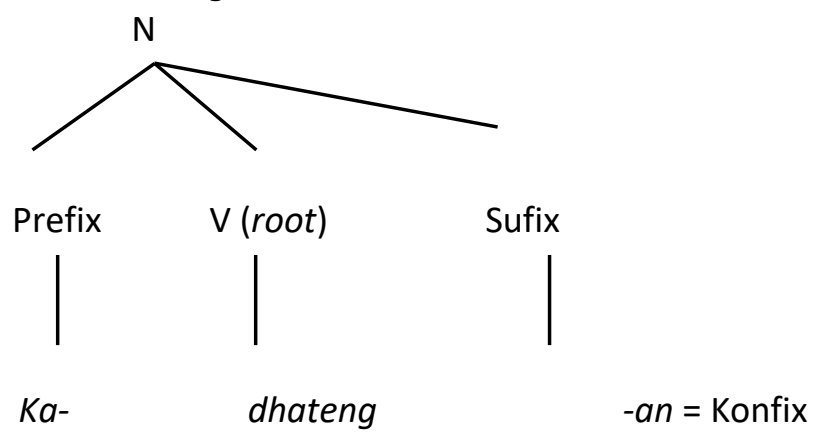

Dateng $(v)+$ confix / ka -an / = kadatengan (n)

Diagram di atas menunjukkan bahwa konfiks menempel pada akar kata dateng (datang), yang akarnya adalah kata kerja. Kemudian, kelas kata tersebut akan berubah menjadi kata benda setelah mendapat tambahan konfiks -an, kadhatengan (kedatangan). Selain itu, telah disebutkan bahwa penambahan imbuhan akan mengubah arti dan fungsi kelas kata. Jadi, ketika arti kata berubah, fungsi kelas kata secara otomatis berubah. Ketika konfiks ( $a-a n)$ melekat pada kata kerja, itu menjadi kata benda (Mardatillah et al., 2020; Muslimah et al., 2019). Nominalisasi deverbal terkadang menyebabkan keadaan ambigu antara kedua bacaan tergantung pada sifat independen dari basis verbal (Fabregas, A. \& R. Marin, 2011). Gagasan peristiwa di dalam nominal, tipologi nominal turunan, korelasi antara sifat morfo-sintaksis dan semantik dalam domain verbal, realisasi argumen dan perbedaan aspek membuka jalan untuk pemahaman yang lebih baik tentang nominalisasi (Roy, I. \& E. Soare, 2011). Kata benda denominal dengan nominalisasi deadjectival mendukungan empiris baru untuk teori kategori leksikal Baker, yang bertentangan dengan teori yang mengasumsikan paralelisme yang lebih kuat di berbagai kategori leksikal (Baker, M.C. \& B. G. Gondo, 2020).

\section{Simpulan}

Berdasarkan hasil penelitian terdapat empat jenis afiks dalam bahasa Madura, yaitu; awalan, sisipan, akhiran, dan konfiks (awalan dan akhiran). Ketika afiksasi Madura menempel pada bentuk dasar, dapat menyebabkan proses morfologis, fonologis dan semantik dalam pembentukannya. Afiksasi yang paling banyak ditemukan dalam cerpen berjudul Tora (satengkes carpan Madura) adalah konfiks. Terlihat bahwa konfiks memberikan kontribusi paling besar terhadap proses kata benda yang diturunkan dari kata kerja. Fungsi nominalisasi adalah untuk mengubah kategori kelas kata, seperti; kata kerja menjadi kata benda. Selain dapat mengubah fungsi, kelas kata juga dapat mengubah makna seperti yang telah dijelaskan pada pembahasan.

\section{Daftar Pustaka}

Aditya Dharma, I. M. (2019). Pengembangan Buku Cerita Anak Bergambar Dengan Insersi Budaya Lokal Bali Terhadap Minat Baca Dan Sikap Siswa Kelas V Sd Kurikulum 2013. Journal for 
Lesson and Learning Studies, 2(1), 53-63. https://doi.org/10.23887/jlls.v2i1.17321.

Astuti, N. I., Sofyan, A., \& Badrudin, A. (2021). Campur Kode dan Struktur Bahasa Madura pada Tugas Menulis Teks Berita Siswa Kelas 8 SMP Negeri 1 Mayang. Jurnal Pendidikan: Riset Dan Konseptual, 5(1), 159. https://doi.org/10.28926/riset_konseptual.v5i1.332.

Baker, M. ., \& Gondo, B. G. (2020). Possession and nominalization in Dan: Evidence for a general theory of categories. Glossa: A Journal of General Linguistics, 5(1), 1-31. https://doi.org/10.5334/gjgl.1018.

Dzarna. (2016). Meningkatkan Pemahaman Santri TPA AL-Ikhlas terhadap Lagu Islami melalui Strategi Memaknai Kata Bahasa Madura ke dalam Bahasa Indonesia. Jurnal Pengabdian Masyarakat IPTEKS, 2(1), 43-55. https://doi.org/10.32528/pengabdian_iptek.v2i1.376.

Effendy, M. H. (2017). Interferensi Gramatikal Bahasa Madura Ke Dalam Bahasa Indonesia. DIALEKTIKA: Jurnal Bahasa, Sastra, Dan Pendidikan Bahasa Dan Sastra Indonesia, 4(1), 1-19. https://doi.org/10.15408/dialektika.v4i1.6997.

Fabregas, A., \& Marin, R. (2011). The role of Aktionsart in deverbal nouns: State nominalizations across languages. Journal of Linguistics, 48(1), 35-70. https://doi.org/10.1017/\$0022226711000351.

Humaidi. (2019). Interferensi antara bahasa arab Dengan bahasa madura (Studi Kasus Pada Mahasiswa Prodi Pendidikan Bahasa Arab STAI Syaichona Moh. Cholil Bangkalan. Syaikhuna: Jurnal Pendidikan Dan Pranata Islam, 10(1), 76-85. https://doi.org/10.36835/syaikhuna.v10i1.3473.

Kharisma, G. I., \& Arvianto, F. (2019). Pengembangan aplikasi android berbentuk education games berbasis budaya lokal untuk keterampilan membaca permulaan bagi siswa kelas $1 \mathrm{SD} / \mathrm{MI}$. Premiere Educandum: Jurnal Pendidikan Dasar Dan Pembelajaran, 9(2), 203. https://doi.org/10.25273/pe.v9i2.5234.

Laily, A. W., Sulistiani, I. R., \& Mutiara Sari Dewi. (2021). Analisis Kearifan Lokal dan Dialek Bahasa Madura dalam Pembelajaran Bahasa Indonesia di SDN Murtajih 3 Pamekasa. Jurnal Pendidikan Madrasah Ibtidaiyah, 3(1). http://riset.unisma.ac.id/index.php/JPMI/article/view/11535.

Mardatillah, H., Nurhayani, I., \& Hamamah. (2020). Variasi Intensitas Kata Sifat Dalam Bahasa Madura. Jurnal Bahasa, Sastra, Dan Pengajarannya, 17(1), 35-50. https://doi.org/10.30957/lingua.v17i1.623.

Muslimah, D., Nurhayati, E. A. A., \& Suhartatik, S. (2019). Afiksasi Bahasa Madura Dialek Sumenep Tingkat Tutur Rendah. Jurnal Pendidikan Bahasa Dan Sastra Indonesia, 1(1), 19-30. https://doi.org/10.36379/estetika.v1i1.3.

Sugiono. (2014). Metode Penelitian Pendidikan Pendekatan Kuantitatif, Kualitatif, dan R\&D. Alfabeta. Sugiono. (2018). Metode Penelitian Pendididkan Pendekatan Kuantitatif, Kualitatif, dan R\&D. Alfabeta.

We, A. Y., \& Fauziah, P. Y. (2020). Tradisi Kearifan Lokal Minangkabau "Manjujai" untuk Stimulasi Perkembangan Anak Usia Dini. Jurnal Obsesi : Jurnal Pendidikan Anak Usia Dini, 5(2), 13391351. https://doi.org/10.31004/obsesi.v5i2.660. 